\title{
Influence of body weight on bone mass, architecture and turnover
}

\author{
Urszula T Iwaniec ${ }^{1,2}$ and Russell T Turner ${ }^{1,2}$ \\ 1Skeletal Biology Laboratory, School of Biological and Population Health Sciences, \\ Oregon State University, Corvallis, Oregon, USA \\ ${ }^{2}$ Center for Healthy Aging Research, Oregon State University, Corvallis, Oregon, USA
}

\author{
Correspondence \\ should be addressed \\ to U T Iwaniec \\ Email \\ urszula.iwaniec@ \\ oregonstate.edu
}

\begin{abstract}
Weight-dependent loading of the skeleton plays an important role in establishing and maintaining bone mass and strength. This review focuses on mechanical signaling induced by body weight as an essential mechanism for maintaining bone health. In addition, the skeletal effects of deviation from normal weight are discussed. The magnitude of mechanical strain experienced by bone during normal activities is remarkably similar among vertebrates, regardless of size, supporting the existence of a conserved regulatory mechanism, or mechanostat, that senses mechanical strain. The mechanostat functions as an adaptive mechanism to optimize bone mass and architecture based on prevailing mechanical strain. Changes in weight, due to altered mass, weightlessness (spaceflight), and hypergravity (modeled by centrifugation), induce an adaptive skeletal response. However, the precise mechanisms governing the skeletal response are incompletely understood. Furthermore, establishing whether the adaptive response maintains the mechanical competence of the skeleton has proven difficult, necessitating the development of surrogate measures of bone quality. The mechanostat is influenced by regulatory inputs to facilitate non-mechanical functions of the skeleton, such as mineral homeostasis, as well as hormones and energy/nutrient availability that support bone metabolism. Although the skeleton is very capable of adapting to changes in weight, the mechanostat has limits. At the limits, extreme deviations from normal weight and body composition are associated with impaired optimization of bone strength to prevailing body size.
\end{abstract}
Key Words
- osteoporosis
- mechanical strain
- fracture risk
- weight change
- leptin

Journal of Endocrinology (2016) 230, R115-R130

\section{Introduction}

The skeleton is a complex multifunctional organ system that, in adults, comprises 206 bones. The acquisition of bone mass occurs primarily during childhood and the decade following puberty with peak bone mass achieved in the third to fourth decade of life (Baxter-Jones et al. 2011). Bone loss may be an inevitable consequence of aging. However, the rate of loss has been shown to differ greatly among individuals (Cauley et al. 2009).
Low peak bone mass and excessive age-related bone loss predispose individuals to osteoporosis, an important underlying risk factor for fragility fractures (Chevalley et al. 2012). Factors influencing skeletal dynamics over the lifecycle are under investigation; the usual suspects, including genetic variation, disturbed mineral homeostasis, gender, reproductive status, diet, physical activity, and body weight, have each been shown to 
be important. However, in spite of major advances, current understanding is inadequate to fully explain all of the variation in fracture risk.

Physical attributes and physiological functions vary among individual bones and among skeletal compartments within a bone. Bone provides a stiff structure required for locomotion, acts as a physical barrier for protection of vital organs, provides a hospitable environment for hematopoietic cell maturation, is an important adipose tissue depot, is an endocrine organ, and a dependable and rapidly mobilizable reservoir for calcium and other minerals. Significant throughout life, the mineral depot in bone is particularly important during catabolic conditions such as late pregnancy, lactation and prolonged fasting. The skeleton influences and is, in turn, influenced by tissues within the bone marrow (hematopoietic, adipose and immune), adjacent tissues (muscle, cartilage, tendons and ligaments), and remote tissues (endocrine, gastrointestinal, kidney, sensory and sympathetic nervous systems). As a consequence of competing responsibilities and regulatory inputs, optimization of bone mass, architecture and turnover for one function could potentially compromise other critical functions (Turner 2001). This can be illustrated by considering the skeletal response to inadequate dietary calcium. Failure to maintain levels of ionic calcium within narrow limits has immediate, potentially life-threatening consequences. Although the skeleton nearly always contains mineral reserves sufficient to balance serum calcium requirements, the resulting bone loss associated with chronic suboptimal dietary calcium will likely reduce the mechanical competence of bone and increase fracture risk. Similarly, pathologies such as hemophilia and anemia involving marrow can place demands on the skeleton that can compromise its mechanical function. Specifically, chronic anemia results in reduced BMD and increased fracture risk due to osteoclast-mediated expansion of the bone marrow cavity in response to increased need for hematopoiesis (Vogiatzi et al. 2005, Almeida \& Roberts 2005, Perisano et al. 2012, Recht et al. 2013). The high rate of fragility fractures in the aged, with an annual rate of over nine million worldwide, testifies to the inability of the skeleton to always maintain sufficient mechanical competence (Kanis et al. 2012).

Body weight can influence a multitude of physiological functions. Not surprisingly, there is a close association between bone mass and weight during growth, and preservation of this relationship throughout life is vital to bone health. The direct pathway for weight to influence bone is via mechanical loading. This review focuses on mechanical signaling as an essential mechanism for coupling bone mass to changes in body weight during growth and adulthood. The influence of weight change, ranging from weightlessness to hypergravity, is also considered. Finally, factors that result in disturbances in the relationship between weight and bone mass are discussed. For additional perspectives, please see reviews by Dimitri and coworkers (2012) and Shapses and Sukumar (2012).

\section{Mechanical loading and skeletal adaptation: mechanostat theory}

The skeleton serves multiple mechanical functions: (1) application of mechanical forces (e.g., jaws and fingers); (2) resisting mechanical forces (e.g., weight-bearing bones); (3) providing a scaffold for the attachment of ligaments and tendons required for locomotion (e.g., long bones); and (4) protecting vital organs (e.g., ribs, vertebrae, and skull). Body weight exhibits minimal dayto-day variation. However, static load and the resulting deformation of bone (mechanical strain) generated by weight depend upon posture. For example, standing on one leg places a higher load on weight-bearing bones of the lower limb than standing on both legs, whereas transferring to a sitting or lying prone position alters the direction as well as reduces the magnitude of limb loading. These forms of skeletal loading are static; the loads are less than body weight and occur over sustained durations of seconds or longer. The larger mechanical loads applied during physical activities such as walking subject loaded bones to higher peak strain levels. Skeletal loading associated with physical activity is dynamic because loads change rapidly in magnitude and direction and peak strain is maintained for short durations (ms). During walking, the lower limbs are subjected to peak loads equivalent to $\sim 1.5$ times the body weight with the interval between strides being $\sim 1 \mathrm{~Hz}$ ( 1 cycle/s) (Fritton et al. 2000, Al Nazer et al. 2008). More intense physical activates, such as those that occur in many sports, place even greater strains on loaded portions of the skeleton.

The maximum mechanical strain levels in bone during activities of normal living are well below levels capable of inducing catastrophic failure. Furthermore, the magnitude of strain during normal activities is remarkably similar among vertebrates, regardless of size, supporting the existence of a conserved regulatory mechanism, or mechanostat, that senses strain (Rubin \& Lanyon 1984). When peak strain levels deviate above or below this set

Published by Bioscientifica Ltd. 
A
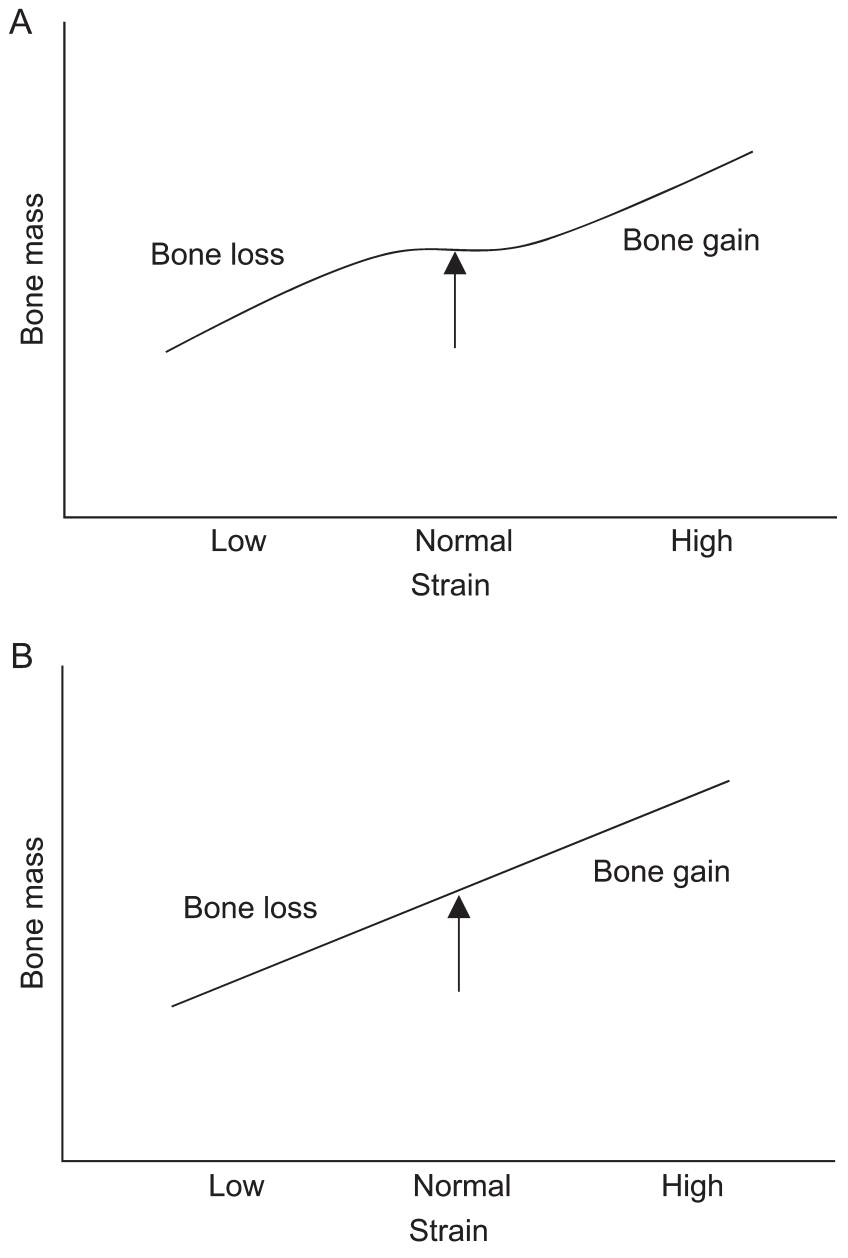

Figure 1

The mechanostat is hypothesized as a mechanism that regulates bone mass in response to changes in mechanical strain. As originally envisioned (A), strain levels consistently falling below the lower boundary lead to an adaptive response where bone is lost, increasing strain. Strain levels consistently exceeding the upper boundary lead to an adaptive response where bone is gained, decreasing strain. Based on this model, there is a zone between upper and lower boundaries where strain differences do not evoke an adaptive response (Frost 1987). An alternative model has been proposed (B) where strain levels below or above a set point that is bone specific evokes an adaptive response (Skerry 2006). Although some studies suggest that moderate weight changes need not evoke an adaptive response (see text), other findings are consistent with the alternative model (Fig. 2).

point, a compensatory mechanism is initiated, which results in addition of bone due to excessive strain or removal of bone due to insufficient strain, maintaining a low risk for catastrophic failure without incurring the metabolic costs associated with forming and maintaining unnecessary bone (Fig. 1).

The mechanostat model predicts that incremental overall increases in weight can increase bone mass and alter bone architecture by inducing an adaptive

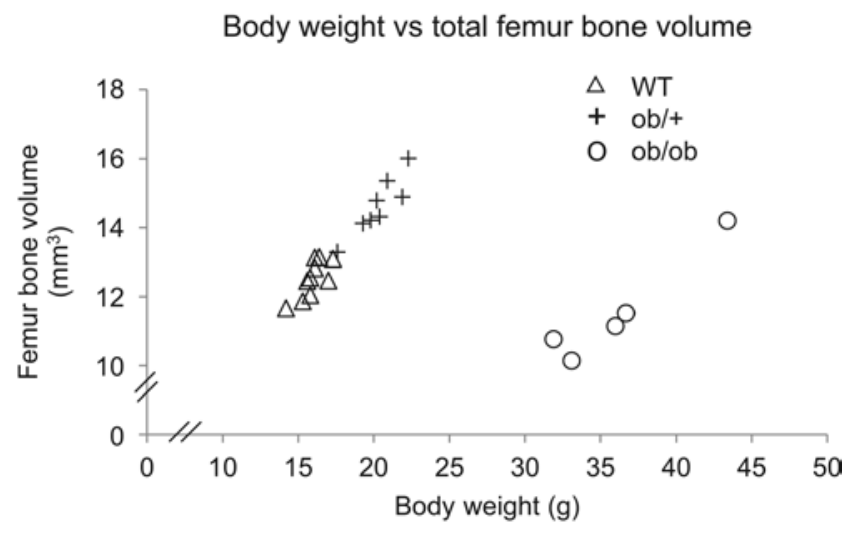

Figure 2

Leptin alters the sensitivity of the skeleton to body weight changes. Total femur mass is strongly associated with body weight in 7-week-old female WT, partially leptin-deficient $o b /+$, and leptin-deficient ob/ob mice fed a normal diet. ob/+ have near normal leptin levels due to increased fat mass and demonstrate an association between body weight and bone mass nearly identical to WT mice. In contrast, ob/ob mice require a much higher body weight to achieve a bone mass equivalent to WT. Please note that the slope of the regression lines is less than unity ( 0.49 for WT and $o b /+$ mice and 0.34 for ob/ob mice); increasing body weight by $50 \%$ in a WT mouse would be expected to lead to $25 \%$ increase in bone mass. Reproduced, with permission, from Philbrick KA, Turner RT, Branscum AJ, Wong CP \& Iwaniec UT (2015) Paradoxical effects of partial leptin deficiency on bone in growing female mice, The Anatomical Record 298 2018-2029. Copyright 2015 Wiley Periodicals, Inc.

response to increased mechanical loads. Lean mass may have additional importance as a contributor to weightdependent skeletal loading because muscles are attached to bone via tendons and larger and more powerful muscles can deliver greater mechanical loads directly to bone. We emphasize "can" because mechanostatmediated adaptations, as originally envisioned, only occur when an upper or lower threshold strain is violated (Frost 1987). However, recent studies performed in mice suggest that the skeleton's adaptive response to mechanical loading is essentially linear over a wide range of strain (Fig. 1) (Sugiyama et al. 2012). This finding is supported by the strong association between weight and bone mass in mice (Fig. 2).

The mechanostat functions to help "optimize" the ability of bone to resist loads conferred by activities of normal living but not the atypical loads often experienced during falls (Silva 2007). This is important because atypical loads are responsible for the majority of low-trauma fractures in children and the elderly. In this regard, the highest rates of fractures due to falling occur in prepubertal boys and elderly women, indicating that the skeleton exhibits a low-safety factor (failure load/peak load) in these two groups. http://joe.endocrinology-journals.org DOI: 10.1530/JOE-16-0089
(C) 2016 Society for Endocrinology Printed in Great Britain
Published by Bioscientifica Ltd. 
Changes in weight necessarily precede skeletal adaptation to changes in mechanical loads. This delay in adaptive response may contribute to the high fracture rate in rapidly growing children. Additionally, the dynamics of bone structure change immediately before and during pubertal growth may partially explain the high rate of fractures. During rapid growth, addition of bone to periosteal bone surfaces is slow compared with bone elongation, resulting in inadequate cortical thickness for bone length (Clark et al. 2006, Rauch 2012). Overweight children appear to be especially prone to fracture (Cole et al. 2012, Dimitri et al. 2012). Studies employing highresolution peripheral quantitative computed tomography (HR-pQCT) and finite element analyses suggest that although childhood obesity alters radial and tibial microstructure, these adaptations are inadequate to compensate for the increased loading potential from a fall (Kim et al. 2013, Dimitri et al. 2015). Although higher body weight can increase mechanical loading on bone and, as a consequence, increase bone mass or alter microarchitecture to improve bone quality, it also has the potential to increase the magnitude of atypical loads that are often responsible for a fracture. Thus, weightassociated increases in mechanical strain would lower the safety factor until skeletal adaptation is completed.

Bones change in size, mass, density, and architecture through the processes of growth, modeling and remodeling. Most bones grow in length through endochondral ossification where primary spongiosa created by osteoclast-mediated resorption of calcified cartilage is replaced by bone through osteoblast-mediated deposition of bone matrix. Bones also grow in size due to osteoblasts depositing bone matrix onto the periosteal surface. Modeling refers to changes in bone architecture where bone is added to a preexisting bone surface without a requirement for prior bone resorption or by which bone is resorbed from a bone surface without initiating subsequent bone formation. Remodeling is initiated when osteoclasts are recruited to quiescent bone surfaces where they degrade bone. Osteoblasts are then recruited to the resorption site where they secrete matrix that undergoes mineralization to form bone to complete a remodeling cycle. When bone formation is tightly coupled to bone resorption, there is minimal change in bone architecture following completion of bone remodeling. In the process of bone formation during growth, modeling, or remodeling, some osteoblasts become quiescent lining cells whereas others are incorporated into bone matrix and become osteocytes.
Osteocytes, through their intricate network of lacunae and interconnecting canaliculi, play an essential role in mechanosignal transduction. Osteocytes embedded in a mineralized matrix experience straininduced interstitial fluid flow and fluid shear stress resulting in activation of signaling pathways that regulate bone turnover (Govey et al. 2015). Mechanoreceptors on osteocytes fall into three general classes: ion channels, G-protein-coupled receptors, and cytoskeletal/integrin complexes (Robling 2012). Mechanoactivation of these receptors on osteocytes results in transduction of signals to cells lining bone surfaces that communicate mechanical strain magnitude and distribution.

Bone lining cells and osteoblasts cover the majority of bone surfaces and are interconnected by gap junctions, allowing intracellular communication via ions and small molecules. Gap junctions and ion channels are also used to communicate signals from osteocytes to osteoblast lineage cells (Lloyd et al. 2014). Additionally, osteocytes generate soluble factors, including fibroblast growth factor 23, sclerostin, tumor necrosis factor ligand superfamily member 11 and dickkoph homolog 1 that regulate bone turnover (Goldring 2015). Several mechanically regulated intracellular signaling cascades have been described, including activation of kinases (Akt, MAPK and FAK), catenin beta 1, GTPases, and calcium signaling (Thompson et al. 2012). Additionally, nitric oxide signaling (Klein-Nulend et al. 2014) and BMP signaling (Kopf et al. 2014) play important roles in the skeletal response to mechanical loads.

The signaling pathways mentioned above are not unique to mechanoregulation (Price et al. 2011) and the state of our knowledge is inadequate to accurately predict the skeletal consequences of manipulating individual pathways. To date, the effects of mechanical signaling on the human skeleton have been studied primarily by altering the applied loads. This is accomplished by increasing physical activity or by evaluating the skeletal response to changes in body weight. Based on extensive observational and intervention studies in humans and animal models, several principles emerge (Skerry 2006): (1) the skeleton responds to mechanical strain stimulus, but the strain stimulus is different in different parts of the skeleton; (2) peak strain magnitude, duration, rate of change and frequency are among the important variables that impact mechanosignal transduction; (3) the efficacy of the mechanostat in maintaining bone mass and quality diminishes with age; and (4) mechanical signal transduction can be influenced by systemic factors such as hormones, cytokines and nutritional status.

Published by Bioscientifica Ltd 
Peak strain is dependent on the magnitude of force applied to bone. Force is, in turn, proportional to mass and velocity. Changing either parameter will change strain, which, in turn, has the potential to influence bone microarchitecture. Increasing mechanical strain has been used as a strategy to develop biomechanical based interventions to improve bone health (Rittweger 2008). Increasing mechanical strain to increase bone mass has been found to be more effective before puberty than in adults (Gunter et al. 2008). High-impact loading during jumping (increased velocity) has proven to be effective in increasing bone mass in children in part by increasing bone size. Importantly, this form of highimpact exercise was shown to confer lasting benefit (Gunter et al. 2008). In adults, increasing mechanical loading by wearing weighted vests (increased mass) does not increase bone mass but appears to slow age-related bone loss (Snow et al. 2000).

\section{Weightlessness}

The importance of static and dynamic weight bearing on the skeleton has been investigated in humans and animals subjected to spaceflight or ground-based models for spaceflight. An astronaut in the low Earth orbit is essentially weightless due to the astronaut and surroundings being uniformly accelerated toward the Earth. Although mass of the astronaut remains constant, static and dynamic loading of the skeleton essentially cease because there is no net external force to induce changes in strain energy within bone tissue. In groundbased models for weightlessness (hindlimb unweighting), dynamic and static loading of portions of the skeleton are reduced (Morey et al. 1979).

Astronauts typically lose bone during exposure to weightlessness, but the pattern of bone loss shows considerable site specificity (Orwoll et al. 2013, Sibonga 2013). In general, bone loss is confined to sites subjected to high levels of dynamic weight bearing. Bone mineral density (BMD) in crewmembers aboard the International Space Station (ISS) showed precipitous declines at weight-bearing sites, including the hip and spine after a typical 6-mo mission but negligible impact at many other skeletal sites (Sibonga et al. 2015). Forces measured during treadmill walking and running on the ISS, using in-shoe monitors, were reduced by 25 and $46 \%$, respectively, compared with similar activities on the Earth. A mean calculated decrease of $25 \%$ in the daily load experienced by the lower extremity was associated with BMD decreases of 0.7 and $0.8 \%$ per month in the femoral neck and lumbar spine, respectively (Cavanagh et al. 2010). The rate of bone loss observed in these male astronauts greatly exceeds the rapid bone loss observed in women following menopause. Long-duration bed rest also results in bone loss (Spector et al. 2009). In addition to bone loss, bed rest results in an increase in marrow adipose tissue (MAT) (Trudel et al. 2009). MAT has not been investigated in astronauts but has been shown to increase in rats subjected to weightlessness and hindlimb unweighting (Jee et al. 1983, Tian et al. 2011, Keune et al. 2016). The similarity in skeletal response to weightlessness and ground-based models for weightlessness argue that static loads generated by weight have little direct effect on the skeleton, whereas dynamic loads have important site-specific effects.

Human spaceflight and long-duration bed rest studies have been performed exclusively in adults. Thus, they provide little insight into the role of weight on bone accrual during growth. On the other hand, animal studies focusing on the skeletal effects of weightlessness have generally been performed in growing rodents, initially rats and more recently mice (Turner 2000, Keune et al. 2015). Of key importance to this review is the observed reduction of bone accrual onto periosteal surfaces of weight-bearing long bones during weightlessness followed by normalization upon reweighting (Sessions et al. 1989). Additionally, site-specific reductions in cancellous bone mass have been reported following weightlessness in rodents and astronauts (Vico et al. 2000, Keune et al. 2015). Furthermore, the deficiency in bone accrual was shown to have a negative effect on bone strength (Sessions et al. 1989). Taken together, studies in humans and animals provide strong evidence that weight-dependent mechanical loading of the skeleton plays an important role in establishing and maintaining bone mass and strength.

Rodent studies provide insight into whether the mechanostat is sufficient to fully account for the tight coupling between bone mass and body weight. Bone length is an important determinant of bone mass, but weightlessness had no effect on longitudinal bone growth (Sibonga et al. 2000). Additionally, a strong interaction between weight and estrogen status was identified (Westerlind etal. 1997, Luo etal. 2000). Subsequent groundbased studies in mice further suggest an important role of estrogen receptor signaling in mechanotransduction (Galea et al. 2013, Melville et al. 2015). Finally, although weightlessness and reweighting affect bone mass in opposing directions, the kinetics differ; the time course

Published by Bioscientifica Ltd 
for bone mass changes during unloading is much more rapid than reloading, implying that factors in addition to mechanostat signaling are involved in mediating skeletal adaptation to changes in weight.

Astronauts are healthy and physically active when subjected to weightlessness. They remain physically active yet experience dramatic site-specific bone loss in only 4-6months. The rate of recovery of BMD following restoration of normal weight bearing is much slower than the rate of loss; recovery approximates an exponential function with $50 \%$ restoration of bone requiring $\sim 9$ months and complete restoration requiring several years (Sibonga et al. 2007). This slow recovery occurs in spite of immediate restoration of normal skeletal loading. Similar findings regarding rapid skeletal changes during weightlessness and slow recovery have been reported in rodents (Sessions et al. 1989). These findings suggest that the rate of skeletal adaptation to weight change may depend on the direction as well as magnitude of weight change.

\section{Hypergravity}

Weight is the product of mass and acceleration, the latter typically being the net acceleration imparted by gravity. However, an individual located within an isolated compartment cannot distinguish force imparted by the action of gravity from force imparted by a mechanical device. Hypergravity refers to a force that exceeds that of gravity and is modeled in humans and animals using centrifugation. Hypergravity has been used to investigate physiological adaptation to changes in weight. Male mice subjected to a two-fold increase in weight for 21 days exhibited decreased osteoclast surface and increased osteoblast surface in femur and vertebra, resulting in increased cancellous bone (Gnyubkin et al. 2015). Also, increasing weight 2.8 -fold increased femur density in female rats during a long-duration (810days) study (Jaekel et al. 1977). Increasing body weight three-fold had detrimental effects on the skeleton of mice, but these data are more difficult to interpret because body mass increment slowed compared with normally housed controls, suggesting that the adaptive response to weight are antagonized by physiological stress (Gnyubkin et al. 2015).

The effect of long-duration continuous hypergravity on the human skeleton is unknown. However, the effects of transient increases of 2-6 times body weight in young men during 12 months of training to fly high-performance aircraft have been reported. Increases in thoracic spine
(11\%), pelvis (4.9\%), and total body BMD (3.7\%) were observed, but no changes were noted in the pilots' lumbar spine, arms or legs (Naumann et al. 2001). These findings suggest that large but intermittent increases in 'weight' can have dramatic effects on the human skeleton at sites subjected to increased mechanical loads.

\section{Scaling bone mass to body weight}

Studies performed on microgravity and hypergravity generally support the concept of a gravity continuum where the skeleton continuously adapts to changes in gravitational loading (Wade 2005). Weight generally continues to increase following cessation of linear growth but at a much slower rate, typically $\leq 0.25 \mathrm{~kg} /$ year (Weigle 1990). However, a parallel increase in BMD is not typically observed. A complicating factor in interpreting this apparent discrepancy with the concept of a gravity continuum is that fracture resistance is not solely dependent on BMD. Weight gain in adults is generally accompanied by changes in the relative proportions of lean tissue and fat tissue and changes in fat distribution. An important unanswered question is whether bone mass and quality is appropriate for adult-associated weight gain. Several methods have been used to adjust BMD for differences in body size in children and adults. In children, dual-energy absorptiometry data have been adjusted using univariate and multivariate models that include age, weight, height, BMC, bone area, lean mass, and fat mass as variables (Dimitri et al. 2012). Similar adjustments have been made in adults and in animal models with the simplest adjustment being dividing bone mass by body mass. None of these methods are completely satisfactory because the adjustments typically assume a uniform effect of weight on bone throughout the skeleton. This assumption is not supported by animal studies where bone mass, density, and microarchitecture can be easily determined at multiple locations. Although a strong linear association was shown between body weight and bone mass in young male mice fed a normal diet, the slope of the linear regression was less than unity, indicating that heavier mice normally have less bone/g body weight than lighter mice (Fig. 2). Also, the Pearson's $R$ value ranged from 0.55 to 0.88 , depending on skeletal site and age (Iwaniec et al. 2009), indicating considerable variation in the response of individual bones and bone compartments to weight change during normal growth. In addition, BMD adjustments to weight provide little insight into the amount of bone

Published by Bioscientifica Ltd 
required to provide equivalent mechanical competence in individuals who differ in weight.

The material and mechanical properties of bone are often determined in animal models as a surrogate measure of fracture resistance. During mechanical testing, load (compression, tension, torsion, or bending) is applied directly to bone. This approach can be exquisitely sensitive. For humans, noninvasive imaging methods are being developed to predict bone strength (Bouxsein \& Seeman 2009). However, the methods used in animal models and humans fail to account for the contribution of soft tissue attached to or located immediately adjacent to bone that deforms under mechanical load, thus effectively diminishing the load on bone (Fig. 3). To determine fracture risk, it is necessary to account for the contribution of all tissues involved in dissipating loads during falls and other traumatic injury events. The 'gold standard' for evaluating skeletal loading in vivo is surgical implantation of strain gages onto bone surfaces (Meakin et al. 2014). Unfortunately, strain measurements to determine whether skeletal adaptation in response to weight gain is appropriate to maintain mechanical competence have yet to be performed. A far less precise but clinically meaningful alternative is to evaluate the associations between weight, BMD, and fracture prevalence.

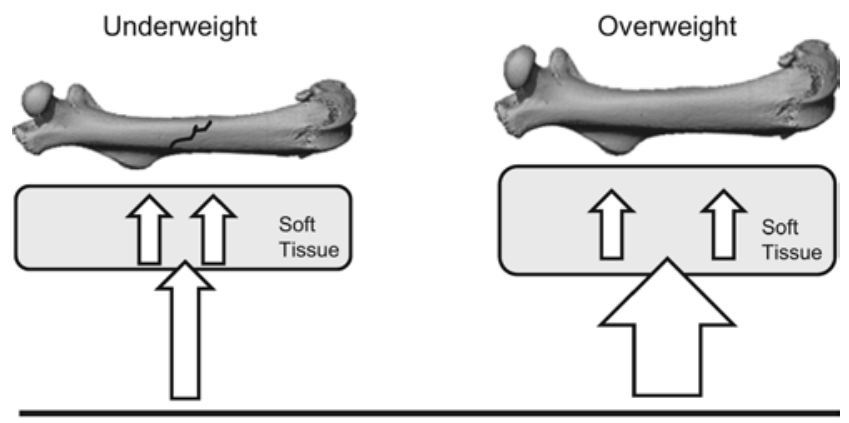

Ground reaction force

\section{Figure 3}

The complex relationship between BMI, BMD, and fracture risk is illustrated in the schematic. Compared with an underweight individual, an overweight individual experiencing a fall from the same height would generate a proportionately greater load on a limb (ground reaction force). However, the presence of greater amount of soft tissue in the heavier individual should attenuate more of the load and distribute the remaining load over a larger bone surface, reducing peak strain such that the effective load could be greater in the lighter individual. Assuming equivalent bone quality, the higher BMD typical in the heavier individual would be a further advantage in reducing strain below that required for a fracture. However, based on epidemiological studies, further increases in weight may provide a diminishing return because the reductions in load during a fall related to soft tissue and higher BMD may not fully compensate for increased weight.
The prevalence of osteoporosis (defined by low BMD) in older men and women is inversely associated with body mass index (BMI, $\mathrm{kg} / \mathrm{m}^{2}$ ), and this association is observed among diverse ethnicities. The prevalence of osteoporosis has been reported to decrease from $45 \%$ in underweight $(\mathrm{BMI}<18.5)$ to $<1 \%$ in obese $(\mathrm{BMI}>30)$ women (Nielson et al. 2012). Hip fracture prevalence was also shown to decrease with increased BMI in men and women. In women, the decrease was progressive; fracture rates decreased from 131 fractures/10,000 person years in underweight women to 50 fractures/10,000 person years in obese women. The relationship was less clear in men. The fracture rates decreased from 56 fractures/10,000 person years in underweight men to 30 fractures/10,000 person years in normal weight men but showed no additional change in the overweight and obese male populations. We interpret these findings as evidence that a higher body weight, at least partially, counteracts age-associated bone loss. It is, however, unlikely that the higher BMD values in overweight and obese adults are exclusively due to a reduction in bone loss during aging. Obesity is associated with higher BMD throughout adulthood (Maïmoun et al. 2016). Reciprocal changes have been observed in the prevalence of obesity and hip fracture rates in the USA over several decades (Wright et al. 2012). Although causality has not been established, weight gain during the same interval may have contributed to reduced hip fracture rates. Reduced fracture risk may not be the only positive benefit of excess weight; if fractures occur, obese and overweight subjects experience lower mortality rate (Prieto-Alhambra et al. 2014).

Despite the generally positive effects of weight on bone health, excess weight may not always be beneficial. The impact of a higher BMI to reduce prevalence of osteoporosis (as defined by BMD) is greater than the contribution of increased BMI to reduce fracture prevalence. When adjusted for BMD (see previous text for caveats), the advantage of being overweight disappears, implying that the main positive impact of increased weight on fracture prevalence is an increase in BMD. At very high BMI, adjusted fracture risk is increased, suggesting a reduction in bone quality (Nielson et al. 2012). Moreover, some obese men and women have unexpectedly low BMD (Greco et al. 2010), and not all studies have found obesity to be protective against fractures (Compston et al. 2011). There are several plausible explanations for the discrepant results. Most studies to date have not segregated the contributions of lean tissue and adipose tissue depots to BMI. This may be important because the contribution of muscle to skeletal loading includes the

Published by Bioscientifica Ltd 
forces generated by muscle as well as weight, whereas the contribution of adipose tissue to skeletal loading is limited to weight. Adipose tissue can also influence bone as a consequence of the tissue's endocrine function. The potential for dysregulation of bone due to excess adipose tissue will be discussed later.

Increased muscle mass and function is likely to contribute to the positive impact of higher BMI on bone health. Sarcopenic and dynapenic obese individuals appear to be at a greater risk for lower BMD and higher fracture risk than obese individuals with normal muscle mass and strength (Scott et al. 2016). This interpretation is consistent with studies reporting that obese osteopenic individuals are at a higher fracture risk compared with normal weight osteopenic individuals (Cawsey et al. 2015). Finally, sarcopenia and dynapenic could result in higher strain levels during a fall or increased fall frequency. Additional research focusing on muscle is required to evaluate these possibilities.

In summary, the full advantage of increasing weight on BMD or fracture rate may not extend to morbid obesity. Also, the precise relationship between weight and fracture rate may depend on fracture type. Increased weight is generally associated with reduction in osteoporotic fractures (hip and vertebral), but in obese subjects, there appears to be an increase in the less common upper arm and ankle fractures (Compston et al. 2011, PrietoAlhambra et al. 2012, Caffarelli et al. 2014, Mpalaris et al. 2015). In general, if weight gain leads to successful skeletal adaptation, as evidenced by an increase in BMD, fracture risk is reduced.

\section{Weight loss}

Weight fluctuations $>0.25 \mathrm{~kg} /$ year occur in adults and can impact BMD and bone turnover (Holbrook \& BarrettConnor 1993, Newman et al. 2005, Von Thun et al. 2014). Weight loss, particularly rapid weight loss induced by dieting, is generally associated with a decrease in BMD, which is not completely restored following a regain in weight. Bariatric surgery is now commonly performed as an alternative to dieting to induce weight loss; in 2013, approximately a half million procedures were performed worldwide (Angrisani et al. 2015). Not surprising, bone loss is a common negative side effect of bariatric surgery (Scibora 2014). Changes in bone microarchitecture, including reduced trabecular number, suggest an accompanying reduction in bone strength (Frederiksen et al. 2016). The reduction in BMD and strength may not be entirely due to weight loss and the magnitude of change varies with the surgical procedure (Hsin et al. 2015). In this regard, bariatric surgery can negatively affect bone health due to impaired absorption of critical micronutrients and alterations in bone-regulating hormones (Yu 2014).

The bone loss associated with weight loss can involve decreased bone formation and/or increased bone resorption (Shapses \& Riedt 2006, Redman et al. 2008, Rector et al. 2009). Studies performed in rodents suggest that endocrine status is one of the factors that affect the cellular mechanisms for bone loss associated with skeletal unweighting. Cancellous bone loss in unweighted hindlimbs of normal male and female rats was due to decreased bone formation, but in ovariectomized rats was due to increased bone resorption (Hefferan et al. 2003). Changes in energy intake are often responsible for changes in weight in adults. In skeletally mature mice, reducing energy to $60 \%$ of normal resulted in cortical bone loss in femur with preservation of cancellous bone (Hamrick et al. 2008). As little as a 5\% reduction in body weight in adult female rats induced by caloric restriction was accompanied by decreased bone formation, increased bone resorption, and cancellous bone loss (Turner \& Iwaniec 2011). These findings contrast with the lack of an effect of a $21 \%$ increase in body weight on bone mass, architecture, and turnover in skeletally mature rats (Turner \& Iwaniec 2010). The rapidity of the bone loss during severe caloric restriction as well as the failure of weight gain resulting from moderately increased energy intake to increase bone mass are not easily explained by mechanostat theory.

\section{Energy homeostasis}

Several hormones are intimately associated with skeletal growth, maturation, and turnover. These include pituitary-, gonadal-, thyroid- and adipocyte-derived hormones. Optimal growth is critically dependent on adequate energy availability, and energy insufficiency reduces secretion and/or antagonizes the actions of growth-promoting hormones. The adipocyte-derived hormone leptin is of particular interest because there is strong evidence that leptin acts to regulate bone cell differentiation and function at multiple levels, via direct actions on skeletal tissues and indirectly through modulation of bone-regulating hormones and energy homeostasis. There is also evidence that leptin plays a role in mechanostat signaling.

Published by Bioscientifica Ltd. 
Leptin is produced primarily by adipocytes and leptin levels in blood are positively associated with adipose tissue mass (Friedman \& Halaas 1998). The hormone crosses the blood-brain barrier and acts at the hypothalamus to communicate the size of peripheral energy stores (Harris 2013). Notably, leptin acts to reduce appetite and increase energy expenditure (Ahima \& Flier 2000). Leptin deficiency due to inactivation of the leptin $(o b)$ gene results in morbid obesity (Campfield et al. 1995, Montague et al. 1997). The excess weight in leptin-deficient $o b / o b$ mice is the result of a combination of hyperphagia and reduced thermogenesis (Hwa et al. 1996). In addition, leptin deficiency in mice results in hypogonadism (Barkan et al. 2005), elevated corticosteroid levels (Saito \& Bray 1983), impaired thermoregulation (Trayhurn \& James 1978), and impaired growth hormone signaling (Luque et al. 2007). Thus, when leptin levels are very low, signaling low-energy availability, key regulatory pathways required for growth and reproduction are suppressed and as a consequence, bone growth, maturation, and turnover are impaired.

Obesity due to loss-of-function mutations in the gene for leptin or its receptor is very rare in humans. However, despite absence of leptin signaling and hypogonadism, bone age was accelerated in a prepubertal female child and BMD was increased in an older girl with loss-of-function mutation in the receptor for leptin (Hannema et al. 2016). These findings contrast with individuals with low leptin production associated with anorexia or lipodystrophy. In these individuals, very low leptin levels are associated with low BMD and leptin treatment was shown to increase bone mass (Mantzoros et al. 2011, Sienkiewicz et al. 2011). These divergent observations may be explained if metabolic changes secondary to and/or responsible for leptin deficiency affect bone metabolism. This conclusion is supported by studies performed in leptin-deficient $o b / o b$ and partial leptin-deficient $o b /+$ mice where weight, adiposity, and serum glucose levels were associated with important leptin-independent differences in bone mass, architecture, and metabolism (Turner et al. 2014, Philbrick et al. 2015).

\section{Leptin and mechanosignaling}

There is a positive association between body weight and bone mass in wild-type (WT) mice, which is preserved in mice heterozygous (ob/+) for the obesity gene (Fig. 2) (Philbrick et al. 2015). ob/+ mice have a reduced ability to generate leptin but compensate for this deficiency by increasing adipose tissue. Although there is also a positive association between body weight and total femur bone volume in $o b / o b$ mice (Iwaniec et al. 2009), the presence of leptin appears to dramatically sensitize the skeletal response to increased body weight (Philbrick et al. 2015). This conclusion is supported by evidence that leptin modulates mechanosensitivity of the skeleton (Baek \& Bloomfield 2009, Kapur et al. 2010). However, other mechanisms are plausible. Estrogen alters the mechanosensitivity of the skeleton by increasing the set point at which bone responds to mechanical load (Luo et al. 2000). As ob/ob mice are hypogonadal, low estrogen levels could contribute to the relative insensitivity of $o b / o b$ mice to increased weight. Alternatively, it is possible that one or more cytokines produced by the abundant adipose tissue antagonize the positive effect of weight gain on bone mass in these mice.

Leptin attenuates the negative skeletal effects of unweighting and weight loss. Food restriction lowers serum leptin levels and enhances the negative effects of hindlimb unweighting (Baek et al. 2008), which, in turn, are attenuated by leptin treatment (Baek \& Bloomfield 2009). The positive effects of leptin appear to be mediated by peripheral leptin signaling because administering high levels of leptin into the hypothalamus not only resulted in weight loss and lower serum leptin levels but exaggerated bone loss in the non-weight-bearing limbs of hindlimb unweighted rodents (Martin et al. 2008). Weight loss typically results in decreased leptin levels (Hamann \& Matthaei 1996), reduced bone accrual during growth (Devlin et al. 2010), and accelerated age-related bone loss (Talbott et al. 2001, Turner \& Iwaniec 2011). Importantly, leptin treatment attenuates the inhibitory effects of caloric restriction on bone growth (Goldstone et al. 2002, Gat-Yablonski et al. 2004). Furthermore, leptin administered at supraphysiological levels was reported to maintain BMD despite inducing weight loss (Stunes et al. 2012). These studies identify leptin as playing a key role in coupling bone metabolism to energy availability. Leptin appears to accomplish this role by a variety of mechanisms, including modulating mechanosignaling.

\section{Dysfunction}

The mechanostat is not infallible as witnessed by chronic bone loss in elderly women and men. The dramatic increase in atraumatic fractures, especially notable in women having low and normal BMI, implies that the mechanostat becomes less effective with advancing age in maintaining the biomechanical components of the

Published by Bioscientifica Ltd 
skeleton. Several explanations for this failure have been proposed, including a parallel age-associated decrease in muscle mass, reduced levels of physical activity, and altered levels of bone-regulating hormones (Faulkner et al. 2007, Ribeiro \& Kehayias 2014). Reductions in muscle mass and weight-bearing physical activity clearly have the potential to decrease peak mechanical loads on the skeleton. The skeletal adaptation to reduced loading could then lower bone mass to a level that restores strain to pre-muscle loss levels. An age-related decrease in growth hormone secretion (Melmed 2013, Sattler 2013) contributes to muscle atrophy and bone loss in humans (Kuzma et al. 2013), suggesting that growth hormone facilitates the mechanostat through its anabolic actions on bone. Notably, growth hormone had similar anabolic effects on bone in weight-bearing and weightless rats (Turner 1995), a finding that suggests that reduced skeletal loading does not impair the skeletal response to growth hormone.

Gender differences are important to bone accrual during growth and bone loss during aging. Females accumulate more bone at puberty than is required to support the skeleton's mechanical requirements (Wang et al. 2015) and lose bone following menopause at a more rapid rate than aging males (Clarke \& Khosla 2010). Postmenopausal bone loss is prevented with hormone replacement. There are multiple lines of evidence that estrogen acts physiologically to modulate the sensitivity of the mechanostat to mechanical loads. Bone in excess of the minimum required for mechanical function would be beneficial to provide minerals for bone development and growth during pregnancy and lactation (Kovacs 2005, Clarke \& Khosla 2010). Animal studies further support an important role for estrogen in modulating the skeletal response to mechanical loading (Westerlind et al. 1997). Reduced dynamic loading (Turner et al. 1998) and weightlessness (Keune et al. 2015) result in bone- and bone-compartment-specific further bone loss in estrogen-deficient rats. Increased skeletal loading can attenuate estrogen deficiency-associated bone loss, whereas increased estrogen levels can attenuate bone loss associated with reduced mechanical loading (Westerlind et al. 1997). Thus, altered endocrine status during aging may contribute to chronic bone loss by multiple mechanisms that are not completely counteracted by the mechanostat. In some cases, hormone action (e.g., growth hormone) on bone appears to be independent of the mechanostat, whereas in other cases, the hormone (e.g., estrogen and leptin) is an integral component of the mechanisms mediating mechanosignaling.

\section{High-fat diet}

Based on mechanostat theory, increased body weight should attenuate age-related decline in bone mass by increasing skeletal loading, and as described earlier, there is evidence that this indeed occurs. However, there is also creditable evidence that underfeeding and overfeeding can impair the ability of the skeleton to fully adapt to mechanical loads. In regard to overfeeding, there has been a great deal of recent interest regarding the impact of specific components of the diet (e.g., fat) on bone health.

Bone-compartment-specific increases and decreases in bone mass have been reported in growing mice fed high-fat diets, but most studies report negative effects. Several mechanisms have been proposed to explain the negative effect of excess fat on rodent bone. Obesity results in chronic mild inflammation and insulin resistance (Xu et al. 2003), conditions that could negatively affect bone turnover (Hardy \& Cooper 2009) and reduce the efficacy of mechanosignaling. Although obesity, in general, may have detrimental effects, fat depots within the skeleton may be particularly damaging because of the proximity to bone cells. An obesity-associated increase in MAT has been suggested as an additional mechanism by which excess weight could negatively affect the skeleton. Anorexia, severe weight loss, and weightlessness each result in increased MAT (Duque 2008, Bredella et al. 2009, Trudel et al. 2009), implicating MAT in bone loss. Bone marrow adipocytes have been implicated in regulating cell differentiation through generation and release of adipokines (Kilroy et al. 2007). Additionally, osteoblasts and adipocytes are derived from the mesenchymal lineage and share a common bone marrow progenitor cell (Prockop 1997). The reciprocal relationship between MAT and bone mass that is often observed is potentially explained by lower osteoblast number (Akune et al. 2004). A deficiency in $\operatorname{PPAR} \gamma$, a key mediator of adipocyte differentiation, reduces marrow fat and enhances osteogenesis (Akune et al. 2004). Thus, increased MAT may reflect altered lineage decision where increased adipocyte differentiation occurs at the expense of osteoblast differentiation. However, a causal relationship between differentiation of adipocytes and osteoblasts has not been established and the results obtained in some studies suggest that adipocyte and osteoblast numbers in bone marrow can be regulated independently (Menagh et al. 2010, Iwaniec \& Turner 2013).

Published by Bioscientifica Ltd. 
When considering diet, species differences need to be considered. Increases in body weight are commonly induced in rodents by feeding energy-dense highfat diets, where fat typically contributes $45-60 \%$ of total energy. Notably, normal rodent diets typically contribute $10-15 \%$ of calories as fat. Although the mechanostat has been conserved among vertebrate species, their dietary requirements show dramatic divergences. Contemporary hunter gatherers show variability in diet that is related to environmental differences, but in most populations, the majority of energy is obtained from animal products (Cordain et al. 2002). Diet reconstruction using stable isotope analysis supports animal products contributing the majority of energy to the diet in preagricultural populations (Eaton \& Eaton III 2000). On the other hand, with the advent of agriculture, $>10,000$ BP humans have successfully adapted to predominantly plant-based diets. Present dietary recommendations for fat vary among countries but are generally between 20 and 35\% of total energy in adults and fat consumption in the USA and Europe is typically at the upper end of the recommended range (Arnett et al. 2000, Vergnaud et al. 2013). In spite of increased prevalence of obesity, in the USA, there has been a progressive decrease in fat consumption, whereas in Europe, fat consumption has increased (Vergnaud et al. 2013). In general, excess weight gain in humans is more associated with excess calories rather than excess in a specific macronutrient. Thus, it is not clear whether the high-fat diets administered to rodents accurately model any commonly consumed human diet.

In spite of uncertainty regarding the precise role of dietary fat, there is growing evidence that excessive fat accrual due to excess calories can have negative effects on BMD (Zhang et al. 2015). Although lean mass is generally positively associated with BMD, the relationship between fat mass and BMD is more complex. Visceral and subcutaneous fat may have independent effects with the former reported to be negatively associated with BMD (Zhang et al. 2015). Additionally, there is evidence for a threshold where the relationship between fat mass and BMD changes from a positive to a negative association (Liu et al. 2014). Successful mechanical adaptation of the skeleton to changes in weight and body composition should confer a reduction in fracture risk. In this regard, the evidence associating BMI and fracture rate is often contradictory. However, there is strong evidence that low-trauma fractures in the obese represent a significant and growing health problem (Premaor et al. 2010, Greco et al. 2015).

\section{Hyperleptinemia: too much of a good thing?}

The regulatory actions of leptin to reduce energy intake are mediated through a hypothalamic relay involving activation of leptin receptors on orexigenic NPY and anorexigenic POMC-expressing neurons (Forbes et al. 2001). In contrast, the physiological actions of leptin to increase bone growth are primarily mediated by systemic actions of the hormone (Turner et al. 2013). Humans and rodents exhibit age-related weight gain and bone loss in spite of increased leptin levels. The failure of increased serum leptin to prevent further weight gain is generally attributed to leptin resistance (Burguera et al. 2000, Banks \& Farrell 2003). As discussed below, it seems plausible that development of leptin resistance may play a causal role for impaired skeletal adaptation to greatly increased body weight. Thus, low leptin levels in severely underweight and leptin resistance associated with obesity may negatively affect optimization of bone mass to body weight.

There are several mechanisms by which obesity could result in skeletal resistance to the bone anabolic actions of leptin, including receptor saturation, reduced receptor levels, and activation of counter regulatory pathways. Based on the affinity of leptin for its receptor in cultured human osteogenic cells $\left(\mathrm{K}_{\mathrm{d}}\right.$ of $\left.\sim 0.4 \mathrm{nM}\right)$, the bone anabolic effects of the hormone would occur at relatively low circulating levels (Hess et al. 2005). Overweight and obese individuals have serum leptin levels in great excess of the $K_{d}$ and would, as a consequence, derive little or no additional benefit of higher hormone levels on bone compared with normal weight individuals (Boden et al. 1996, Weigle et al. 1997). Continuous exposure to high levels of leptin have been shown to result in downregulation of leptin receptor mRNA and protein in the hypothalamus (Martin et al. 2008). However, the impact of hyperleptinemia on leptin receptors in skeletal tissues is unknown. Finally, continuous exposure to high levels of leptin has been shown to increase expression of Socs 3 in the hypothalamus, which in turn blocked leptininduced signal transduction (Bjørbæk et al. 1998). Socs3 is also a potent negative regulator of cytokine signaling in osteoblasts and osteoclasts (Gao \& Van Dyke 2013), but its role in leptin signaling in bone has not been investigated.

\section{Summary and conclusions}

Lifelong maintenance of the mechanical competence of the skeleton requires a bone mass appropriate for

Published by Bioscientifica Ltd. 
body size. Skeletal growth and maturation is regulated by several hormones and is dependent on adequate energy to support growth. The mechanostat functions as an adaptive mechanism to help optimize bone mass and architecture based on prevailing mechanical strain induced by body weight. However, the mechanostat is influenced by regulatory inputs mandating nonmechanical functions of the skeleton, such as mineral homeostasis. Although the skeleton is very capable of adapting to changes in weight, the mechanostat has limits related to magnitude and rate of change in bone mass. Both underweight and obesity are associated with impaired optimization of bone strength. The mechanisms for these deficiencies are unknown but may be related; we speculate that leptin deficiency and leptin resistance may be a common factor contributing to decreased mechanical competence noted in anorectic and obese individuals.

\section{Declaration of interest}

The authors declare that there is no conflict of interest that could be perceived as prejudicing the impartiality of this review.

\section{Funding}

This work was supported by NIH (AR 060913) and NASA (NNX12AL24).

\section{References}

Ahima RS \& Flier JS 2000 Leptin. Annual Review of Physiology 62 413-437. (doi:10.1146/annurev.physiol.62.1.413)

Akune T, Ohba S, Kamekura S, Yamaguchi M, Chung U-I, Kubota N, Terauchi Y, Harada Y, Azuma Y \& Nakamura K 2004 PPAR $\gamma$ insufficiency enhances osteogenesis through osteoblast formation from bone marrow progenitors. Journal of Clinical Investigation 113 846-855. (doi:10.1172/JCI200419900)

Al Nazer R, Rantalainen T, Heinonen A, Sievanen H \& Mikkola A 2008 Flexible multibody simulation approach in the analysis of tibial strain during walking. Journal of Biomechanics 41 1036-1043. (doi:10.1016/j. jbiomech.2007.12.002)

Almeida A \& Roberts I 2005 Bone involvement in sickle cell disease. British Journal of Haematology 129 482-490. (doi:10.1111/j.13652141.2005.05476.x)

Angrisani L, Santonicola A, Iovino P, Formisano G, Buchwald H \& Scopinaro N 2015 Bariatric surgery worldwide 2013. Obesity Surgery 25 1822-1832. (doi:10.1007/s11695-015-1657-z)

Arnett DK, Xiong B, McGovern PG, Blackburn H \& Luepker RV 2000 Secular trends in dietary macronutrient intake in Minneapolis-St, Paul, Minnesota, 1980-1992. American Journal of Epidemiology 152 868-873. (doi:10.1093/aje/152.9.868)

Baek K \& Bloomfield SA 2009 ß2010adrenergic blockade and leptin replacement effectively mitigate disuse bone loss. Journal of Bone and Mineral Research 24 792-799. (doi:10.1359/jbmr.081241)

Baek K, Barlow AA, Allen MR \& Bloomfield SA 2008 Food restriction and simulated microgravity: effects on bone and serum leptin.
Journal of Applied Physiology 104 1086-1093. (doi:10.1152/ japplphysiol.01209.2007)

Banks WA \& Farrell CL 2003 Impaired transport of leptin across the blood-brain barrier in obesity is acquired and reversible. American Journal of Physiology: Endocrinology and Metabolism 285 E10-E15. (doi:10.1152/ajpendo.00468.2002)

Barkan D, Hurgin V, Dekel N, Amsterdam A \& Rubinstein M 2005 Leptin induces ovulation in GnRH-deficient mice. FASEB Journal 19 133-135.

Baxter-Jones AD, Faulkner RA, Forwood MR, Mirwald RL \& Bailey DA 2011 Bone mineral accrual from 8 to 30 years of age: an estimation of peak bone mass. Journal of Bone and Mineral Research 26 1729-1739. (doi:10.1002/jbmr.412)

Bjørbæk C, Elmquist JK, Frantz JD, Shoelson SE \& Flier JS 1998 Identification of SOCS-3 as a potential mediator of central leptin resistance. Molecular Cell 1 619-625. (doi:10.1016/S10972765(00)80062-3)

Boden G, Chen X, Mozzoli M \& Ryan I 1996 Effect of fasting on serum leptin in normal human subjects. Journal of Clinical Endocrinology and Metabolism 81 3419-3423. (doi:10.1210/jc.81.9.3419)

Bouxsein ML \& Seeman E 2009 Quantifying the material and structural determinants of bone strength. Best Practice and Research Clinical Rheumatology 23 741-753. (doi:10.1016/j.berh.2009.09.008)

Bredella MA, Fazeli PK, Miller KK, Misra M, Torriani M, Thomas BJ, Ghomi RH, Rosen CJ \& Klibanski A 2009 Increased bone marrow fat in anorexia nervosa. Journal of Clinical Endocrinology and Metabolism 94 2129-2136. (doi:10.1210/jc.2008-2532)

Burguera B, Couce ME, Curran GL, Jensen MD, Lloyd RV, Cleary MP \& Poduslo JF 2000 Obesity is associated with a decreased leptin transport across the blood-brain barrier in rats. Diabetes $\mathbf{4 9}$ 1219-1223. (doi:10.2337/diabetes.49.7.1219)

Caffarelli C, Alessi C, Nuti R \& Gonnelli S 2014 Divergent effects of obesity on fragility fractures. Clinical Interventions in Aging 9 1629-1636. (doi:10.2147/cia.s64625)

Campfield LA, Smith FJ, Guisez Y, Devos R \& Burn P 1995 Recombinant mouse $\mathrm{OB}$ protein: evidence for a peripheral signal linking adiposity and central neural networks. Science 269 546-549. (doi:10.1126/ science.7624778)

Cauley JA, Lui LY, Barnes D, Ensrud KE, Zmuda JM, Hillier TA, Hochberg MC, Schwartz AV, Yaffe K, Cummings SR, et al. 2009 Successful skeletal aging: a marker of low fracture risk and longevity. The Study of Osteoporotic Fractures (SOF). Journal of Bone and Mineral Research 24 134-143. (doi:10.1359/jbmr.080813)

Cavanagh PR, Genc KO, Gopalakrishnan R, Kuklis MM, Maender CC \& Rice AJ 2010 Foot forces during typical days on the international space station. Journal of Biomechanics 43 2182-2188. (doi:10.1016/j. jbiomech.2010.03.044)

Cawsey S, Padwal R, Sharma A, Wang X, Li S \& Siminoski K 2015 Women with severe obesity and relatively low bone mineral density have increased fracture risk. Osteoporosis International 26 103-111. (doi:10.1007/s00198-014-2833-z)

Chevalley T, Bonjour J-P, Van Rietbergen B, Rizzoli R \& Ferrari S 2012 Fractures in healthy females followed from childhood to early adulthood are associated with later menarcheal age and with impaired bone microstructure at peak bone mass. Journal of Clinical Endocrinology and Metabolism 97 4174-4181. (doi:10.1210/jc.20122561)

Clark EM, Ness AR, Bishop NJ \& Tobias JH 2006 Association between bone mass and fractures in children: a prospective cohort study. Journal of Bone and Mineral Research 21 1489-1495. (doi:10.1359/ jbmr.060601)

Clarke BL \& Khosla S 2010 Female reproductive system and bone. Archives of Biochemistry and Biophysics 503 118-128. (doi:10.1016/j. abb.2010.07.006)

Cole Z, Harvey N, Kim M, Ntani G, Robinson S, Inskip H, Godfrey K, Cooper C, Dennison E \& SWS Study Group 2012 Increased fat mass is associated with increased bone size but reduced volumetric http://joe.endocrinology-journals.org

DOI: $10.1530 / J O E-16-0089$
(C) 2016 Society for Endocrinology Printed in Great Britain 
density in pre pubertal children. Bone 50 562-567. (doi:10.1016/j bone.2011.05.005)

Compston JE, Watts NB, Chapurlat R, Cooper C, Boonen S, Greenspan S, Pfeilschifter J, Silverman S, Diez-Perez A, Lindsay R, et al. 2011 Obesity is not protective against fracture in postmenopausal women: GLOW. American Journal of Medicine 124 1043-1050. (doi:10.1016/j. amjmed.2011.06.013)

Cordain L, Eaton S, Brand Miller J, Mann N \& Hill K 2002 Original communications-the paradoxical nature of hunter-gatherer diets: meat-based, yet non-atherogenic. European Journal of Clinical Nutrition 56 S42. (doi:10.1038/sj.ejcn.1601353)

Devlin MJ, Cloutier AM, Thomas NA, Panus DA, Lotinun S, Pinz I, Baron R, Rosen CJ \& Bouxsein ML 2010 Caloric restriction leads to high marrow adiposity and low bone mass in growing mice. Journal of Bone and Mineral Research 25 2078-2088. (doi:10.1002/jbmr.82)

Dimitri P, Bishop N, Walsh J \& Eastell R 2012 Obesity is a risk factor for fracture in children but is protective against fracture in adults: a paradox. Bone 50 457-466. (doi:10.1016/j.bone.2011.05.011)

Dimitri P, Jacques RM, Paggiosi M, King D, Walsh J, Taylor ZA, Frangi AF, Bishop N \& Eastell R 2015 Leptin may play a role in bone microstructural alterations in obese children. Journal of Clinical Endocrinology and Metabolism 100 594-602. (doi:10.1210/jc.20143199)

Duque G 2008 Bone and fat connection in aging bone. Current Opinion in Rheumatology 20 429-434. (doi:10.1097/BOR.0b013e3283025e9c)

Eaton SB \& Eaton SB III 2000 Paleolithic vs. modern diets-slected pathophysiological implications. European Journal of Nutrition 39 67-70. (doi:10.1007/s003940070032)

Faulkner JA, Larkin LM, Claflin DR \& Brooks SV 2007 Age-related changes in the structure and function of skeletal muscles. Clinical and Experimental Pharmacology and Physiology 34 1091-1096. (doi:10.1111/ j.1440-1681.2007.04752.x)

Forbes S, Bui S, Robinson BR, Hochgeschwender U \& Brennan MB 2001 Integrated control of appetite and fat metabolism by the leptinproopiomelanocortin pathway. PNAS 98 4233-4237. (doi:10.1073/ pnas.071054298)

Frederiksen KD, Hanson S, Hansen S, Brixen K, Gram J, Jorgensen NR \& Stoving RK 2016 Bone structural changes and estimated strength after gastric bypass surgery evaluated by HR-pQCT. Calcified Tissue International 98 253-262. (doi:10.1007/s00223-015-0091-5)

Friedman JM \& Halaas JL 1998 Leptin and the regulation of body weight in mammals. Nature 395 763-770. (doi:10.1038/27376)

Fritton SP, McLeod KJ \& Rubin CT 2000 Quantifying the strain history of bone: spatial uniformity and self-similarity of low-magnitude strains. Journal of Biomechanics 33 317-325. (doi:10.1016/S00219290(99)00210-9)

Frost HM 1987 The mechanostat: a proposed pathogenic mechanism of osteoporoses and the bone mass effects of mechanical and nonmechanical agents. Bone and Mineral 2 73-85.

Galea GL, Price JS \& Lanyon LE 2013 Estrogen receptors' roles in the control of mechanically adaptive bone (re)modeling. Bonekey Reports 2 413. (doi:10.1038/bonekey.2013.147)

Gao A \& Van Dyke TE 2013 Role of suppressors of cytokine signaling 3 in bone inflammatory responses. Frontiers in Immunology 4506. (doi:10.3389/fimmu.2013.00506)

Gat-Yablonski G, Ben-Ari T, Shtaif B, Potievsky O, Moran O, Eshet R, Maor G, Segev Y \& Phillip M 2004 Leptin reverses the inhibitory effect of caloric restriction on longitudinal growth. Endocrinology 145 343-350. (doi:10.1210/en.2003-0910)

Gnyubkin V, Guignandon A, Laroche N, Vanden-Bossche A, Normand M, Lafage-Proust M-H \& Vico L 2015 Effects of chronic hypergravity: from adaptive to deleterious responses in growing mouse skeleton. Journal of Applied Physiology 119 908-917. (doi:10.1152/ japplphysiol.00364.2015)

Goldring SR 2015 The osteocyte: key player in regulating bone turnover. RMD Open 1 e000049. (doi:10.1136/rmdopen-2015-000049)
Goldstone A, Howard J, Lord G, Ghatei M, Gardiner J, Wang Z, Wang R, Girgis S, Bailey C \& Bloom S 2002 Leptin prevents the fall in plasma osteocalcin during starvation in male mice. Biochemical and Biophysical Research Communications 295 475-481. (doi:10.1016/ S0006-291X(02)00697-6)

Govey PM, Kawasawa YI \& Donahue HJ 2015 Mapping the osteocytic cell response to fluid flow using RNA-Seq. Journal of Biomechanics $\mathbf{4 8}$ 4327-4332. (doi:10.1016/j.jbiomech.2015.10.045)

Greco EA, Fornari R, Rossi F, Santiemma V, Prossomariti G, Annoscia C, Aversa A, Brama M, Marini M, Donini LM, et al. 2010 Is obesity protective for osteoporosis? Evaluation of bone mineral density in individuals with high body mass index. International Journal of Clinical Practice 64 817-820. (doi:10.1111/j.1742-1241.2009.02301.x)

Greco EA, Lenzi A \& Migliaccio S 2015 The obesity of bone. Therapeutic Advances in Endocrinology and Metabolism 6 273-286. (doi:10.1177/2042018815611004)

Gunter K, Baxter-Jones AD, Mirwald RL, Almstedt H, Fuchs RK, Durski S \& Snow C 2008 Impact exercise increases BMC during growth: an 8-year longitudinal study. Journal of Bone and Mineral Research 23 986-993. (doi:10.1359/jbmr.071201)

Hamann A \& Matthaei S 1996 Regulation of energy balance by leptin. Experimental and Clinical Endocrinology and Diabetes 104 293-300. (doi:10.1055/s-0029-1211457)

Hamrick MW, Ding KH, Ponnala S, Ferrari SL \& Isales CM 2008 Caloric restriction decreases cortical bone mass but spares trabecular bone in the mouse skeleton: implications for the regulation of bone mass by body weight. Journal of Bone and Mineral Research 23 870-878. (doi:10.1359/jbmr.080213)

Hannema SE, Wit JM, Houdijk ME, van Haeringen A, Bik EC, Verkerk AJ Uitterlinden AG, Kant SG, Oostdijk W, Bakker E, et al. 2016 Novel leptin receptor mutations identified in two girls with severe obesity are associated with increased bone mineral density. Hormone Research in Paediatrics [in press]. (doi:10.1159/000444055)

Hardy R \& Cooper MS 2009 Bone loss in inflammatory disorders. Journal of Endocrinology 201 309-320. (doi:10.1677/JOE-08-0568)

Harris RB 2013 Is leptin the parabiotic "satiety" factor? Past and present interpretations. Appetite 61 111-118. (doi:10.1016/j.appet.2012.08.006)

Hefferan TE, Evans GL, Lotinun S, Zhang M, Morey-Holton E \& Turner RT 2003 Effect of gender on bone turnover in adult rats during simulated weightlessness. Journal of Applied Physiology 95 1775-1780. (doi:10.1152/japplphysiol.00455.2002)

Hess R, Pino AM, Ríos S, Fernández M \& Rodríguez JP 2005 High affinity leptin receptors are present in human mesenchymal stem cells (MSCs) derived from control and osteoporotic donors. Journal of Cellular Biochemistry 94 50-57. (doi:10.1002/jcb.20330)

Holbrook TL \& Barrett-Connor E 1993 The association of lifetime weight and weight control patterns with bone mineral density in an adult community. Bone and Mineral 20 141-149. (doi:10.1016/S0169. 6009(08)80023-2)

Hsin MC, Huang CK, Tai CM, Yeh LR, Kuo HC \& Garg A 2015 A casematched study of the differences in bone mineral density 1 year after 3 different bariatric procedures. Surgery of Obesity and Related Diseases 11 181-185. (doi:10.1016/j.soard.2014.07.008)

Hwa J, Ghibaudi L, Compton D, Fawzi A \& Strader C 1996 Intracerebroventricular injection of leptin increases thermogenesis and mobilizes fat metabolism in ob/ob mice. Hormone and Metabolic Research 28 659-663. (doi:10.1055/s-2007-979873)

Iwaniec UT \& Turner RT 2013 Failure to generate bone marrow adipocytes does not protect mice from ovariectomy-induced osteopenia. Bone 53 145-153. (doi:10.1016/j.bone.2012.11.034)

Iwaniec U, Dube M, Boghossian S, Song H, Helferich W, Turner R \& Kalra S 2009 Body mass influences cortical bone mass independent of leptin signaling. Bone 44 404-412. (doi:10.1016/j.bone.2008.10.058)

Jaekel E, Amtmann E \& Oyama J 1977 Effect of chronic centrifugation on bone density of the rat. Anatomy and Embriology $151223-232$. (doi:10.1007/BF00297483) 
Jee W, Wronski T, Morey E \& Kimmel D 1983 Effects of spaceflight on trabecular bone in rats. American Journal of Physiology: Regulatory, Integrative and Comparative Physiology 244 R310-R314.

Kanis JA, Odén A, McCloskey E, Johansson H, Wahl DA \& Cooper C 2012 A systematic review of hip fracture incidence and probability of fracture worldwide. Osteoporosis International 23 2239-2256. (doi:10.1007/s00198-012-1964-3)

Kapur S, Amoui M, Kesavan C, Wang X, Mohan S, Baylink DJ \& Lau K-HW 2010 Leptin receptor (Lepr) is a negative modulator of bone mechanosensitivity and genetic variations in Lepr may contribute to the differential osteogenic response to mechanical stimulation in the $\mathrm{C} 57 \mathrm{BL} / 6 \mathrm{~J}$ and $\mathrm{C} 3 \mathrm{H} / \mathrm{HeJ}$ pair of mouse strains. Journal of Biological Chemistry 285 37607-37618. (doi:10.1074/jbc.M110.169714)

Keune JA, Branscum AJ, Iwaniec UT \& Turner RT 2015 Effects of spaceflight on bone microarchitecture in the axial and appendicular skeleton in growing ovariectomized rats. Scientific Reports 518671. (doi:10.1038/srep18671)

Keune JA, Philbrick KA, Branscum AJ \& Turner RT 2016 Spaceflightinduced vertebral bone loss in ovariectomized rats is assosicated with increased bone marrow adiposity and no change in bone formation. Microgravity 2 16016. (doi:10.1038/npjmgrav.2016.16)

Kilroy GE, Foster SJ, Wu X, Ruiz J, Sherwood S, Heifetz A, Ludlow JW, Stricker DM, Potiny S \& Green P 2007 Cytokine profile of human adipose-derived stem cells: expression of angiogenic, hematopoietic, and pro-inflammatory factors. Journal of Cellular Physiology $\mathbf{2 1 2}$ 702-709. (doi:10.1002/jcp.21068)

Kim JE, Hsieh MH, Soni BK, Zayzafoon M \& Allison DB 2013 Childhood obesity as a risk factor for bone fracture: a mechanistic study. Obesity 21 1459-1466. (doi:10.1002/oby.20355)

Klein-Nulend J, van Oers RF, Bakker AD \& Bacabac RG 2014 Nitric oxide signaling in mechanical adaptation of bone. Osteoporosis International 25 1427-1437. (doi:10.1007/s00198-013-2590-4)

Kopf J, Paarmann P, Hiepen C, Horbelt D \& Knaus P 2014 BMP growth factor signaling in a biomechanical context. Biofactors 40 171-187. (doi:10.1002/biof.1137)

Kovacs CS 2005 Calcium and bone metabolism during pregnancy and lactation. Journal of Mammary Gland Biology and Neoplasia 10 105-118. (doi:10.1007/s10911-005-5394-0)

Kuzma M, Homerova Z, Dlesk A, Koller T, Killinger Z, Vanuga P, Lazurova I, Tomkova S \& Payer J 2013 Effect of growth hormone on bone status in growth hormone-deficient adults. Bratislarske Lekarske Listy 114 689-695. (doi:10.4149/bll_2013_146)

Liu PY, Ilich JZ, Brummel-Smith K \& Ghosh S 2014 New insight into fat, muscle and bone relationship in women: determining the threshold at which body fat assumes negative relationship with bone mineral density. International Journal of Preventive Medicine 5 1452-1463.

Lloyd SA, Loiselle AE, Zhang Y \& Donahue HJ 2014 Shifting paradigms on the role of connexin43 in the skeletal response to mechanical load. Journal of Bone and Mineral Research 29 275-286. (doi:10.1002/ jbmr.2165)

Luo ZP, Zhang L, Turner RT \& An KN 2000 Effects of mechanical stress/ strain and estrogen on cancellous bone structure predicted by fuzzy decision. IEEE Transections in Biomedical Engineering 47 344-351. (doi:10.1109/10.827295)

Luque RM, Huang ZH, Shah B, Mazzone T \& Kineman RD 2007 Effects of leptin replacement on hypothalamic-pituitary growth hormone axis function and circulating ghrelin levels in ob/ob mice. American Journal of Physiology: Endocrinology and Metabolism 292 E891-E899. (doi:10.1152/ajpendo.00258.2006)

Maïmoun L, Mura T, Leprieur E, Avignon A, Mariano-Goulart D \& Sultan A 2016 Impact of obesity on bone mass throughout adult life: Influence of gender and severity of obesity. Bone $9023-30$ (doi:10.1016/j.bone.2015.11.020)

Mantzoros CS, Magkos F, Brinkoetter M, Sienkiewicz E, Dardeno TA, Kim SY, Hamnvik OP \& Koniaris A 2011 Leptin in human physiology and pathophysiology. American Journal of Physiology: Endocrinology and Metabolism 301 E567-E584. (doi:10.1152/ajpendo.00315.2011)

Martin A, David V, Vico L \& Thomas T 2008 Impaired energetic metabolism after central leptin signaling leads to massive appendicular bone loss in hindlimb-suspended rats. Journal of Bone and Mineral Research 23 2040-2047. (doi:10.1359/jbmr.080708)

Meakin LB, Price JS \& Lanyon LE 2014 The contribution of experimental in vivo models to understanding the mechanisms of adaptation to mechanical loading in bone. Frontiers in Endocrinology 5154. (doi:10.3389/fendo.2014.00154)

Melmed S 2013 Idiopathic adult growth hormone deficiency. Journal of Clinical Endocrinology and Metabolism 98 2187-2197. (doi:10.1210/ jc.2012-4012)

Melville KM, Kelly NH, Surita G, Buchalter DB, Schimenti JC, Main RP, Ross FP \& van der Meulen MC 2015 Effects of deletion of ERalpha in osteoblast-lineage cells on bone mass and adaptation to mechanical loading differ in female and male mice. Journal of Bone and Mineral Research 30 1468-1480. (doi:10.1002/jbmr.2488)

Menagh PJ, Turner RT, Jump DB, Wong CP, Lowry MB, Yakar S, Rosen CJ \& Iwaniec UT 2010 Growth hormone regulates the balance between bone formation and bone marrow adiposity. Journal of Bone and Mineral Research 25 757-768. (doi:10.1359/jbmr.091015)

Montague CT, Farooqi IS, Whitehead JP, Soos MA, Rau H, Wareham NJ, Sewter CP, Digby JE, Mohammed SN \& Hurst JA 1997 Congenital leptin deficiency is associated with severe early-onset obesity in humans. Nature 387 903-907. (doi:10.1038/43185)

Morey E, Sabelman E, Turner R \& Baylink D 1979 A new rat model simulating some aspects of space flight. Physiologist 22 S23.

Mpalaris V, Anagnostis P, Goulis D \& Iakovou I 2015 Complex association between body weight and fracture risk in postmenopausal women. Obesity Reviews 16 225-233. (doi:10.1111/obr.12244)

Naumann FL, Bennell KL \& Wark JD 2001 The effects of +Gz force on the bone mineral density of fighter pilots. Aviation, Space, and Environmental Medicine 72 177-181.

Newman AB, Lee JS, Visser M, Goodpaster BH, Kritchevsky SB, Tylavsky FA, Nevitt M \& Harris TB 2005 Weight change and the conservation of lean mass in old age: the Health, Aging and Body Composition Study. American Journal of Clinical Nutrition $\mathbf{8 2}$ 872-878.

Nielson CM, Srikanth P \& Orwoll ES 2012 Obesity and fracture in men and women: an epidemiologic perspective. Journal of Bone and Mineral Research 27 1-10. (doi:10.1002/jbmr.1486)

Orwoll ES, Adler RA, Amin S, Binkley N, Lewiecki EM, Petak SM, Shapses SA, Sinaki M, Watts NB \& Sibonga JD 2013 Skeletal health in long-duration astronauts: Nature, assessment, and management recommendations from the NASA bone summit. Journal of Bone and Mineral Research 28 1243-1255. (doi:10.1002/jbmr.1948)

Perisano C, Marzetti E, Spinelli MS, Calla CA, Graci C \& Maccauro G 2012 Physiopathology of bone modifications in beta-thalassemia. Anemia 2012 1-5. (doi:10.1155/2012/320737)

Philbrick KA, Turner RT, Branscum AJ, Wong CP \& Iwaniec UT 2015 Paradoxical effects of partial leptin deficiency on bone in growing female mice. Anatomical Record 298 2018-2029. (doi:10.1002/ ar.23267)

Premaor MO, Pilbrow L, Tonkin C, Parker RA \& Compston J 2010 Obesity and fractures in postmenopausal women. Journal of Bone and Mineral Research 25 292-297. (doi:10.1359/jbmr.091004)

Price JS, Sugiyama T, Galea GL, Meakin LB, Sunters A \& Lanyon LE 2011 Role of endocrine and paracrine factors in the adaptation of bone to mechanical loading. Current Osteoporosis Reports 9 76-82. (doi:10.1007/s11914-011-0050-7)

Prieto-Alhambra D, Premaor MO, Fina Aviles F, Hermosilla E, MartinezLaguna D, Carbonell-Abella C, Nogues X, Compston JE \& DiezPerez A 2012 The association between fracture and obesity is site-dependent: a population-based study in postmenopausal women. http://joe.endocrinology-journals.org

DOI: 10.1530/JOE-16-0089
(C) 2016 Society for Endocrinology Printed in Great Britain 
Journal of Bone and Mineral Research 27 294-300. (doi:10.1002/ jbmr.1466)

Prieto-Alhambra D, Premaor MO, Aviles FF, Castro AS, Javaid MK, Nogues X, Arden NK, Cooper C, Compston JE \& Diez-Perez A 2014 Relationship between mortality and BMI after fracture: a populationbased study of men and women aged $\geq 40$ years. Journal of Bone and Mineral Research 29 1737-1744. (doi:10.1002/jbmr.2209)

Prockop DJ 1997 Marrow stromal cells as stem cells for nonhematopoietic tissues. Science 276 71-74. (doi:10.1126/science.276.5309.71)

Rauch F 2012 The dynamics of bone structure development during pubertal growth. Journal of Musculoskeletal and Neuronal Interactions 12 1-6.

Recht M, Liel MS, Turner RT, Klein RF \& Taylor JA 2013 The bone disease associated with factor VIII deficiency in mice is secondary to increased bone resorption. Haemophilia 19 908-912. (doi:10.1111/hae.12195)

Rector RS, Loethen J, Ruebel M, Thomas TR \& Hinton PS 2009 Serum markers of bone turnover are increased by modest weight loss with or without weight-bearing exercise in overweight premenopausal women. Applied Physiology, Nutrition and Metabolism 34 933-941. (doi:10.1139/H09-098)

Redman LM, Rood J, Anton SD, Champagne C, Smith SR \& Ravussin E 2008 Calorie restriction and bone health in young, overweight individuals. Archives of Internal Medicine 168 1859-1866. (doi:10.1001/archinte.168.17.1859)

Ribeiro SM \& Kehayias JJ 2014 Sarcopenia and the analysis of body composition. Advances in Nutrition 5 260-267. (doi:10.3945/ an.113.005256)

Rittweger J 2008 Ten years muscle-bone hypothesis: what have we learned so far?-almost a festschrift. Journal of Musculoskeletal and Neuronal Interactions 8 174-178.

Robling AG 2012 The interaction of biological factors with mechanical signals in bone adaptation: recent developments. Current Osteoporosis Reports 10 126-131. (doi:10.1007/s11914-012-0099-y)

Rubin CT \& Lanyon LE 1984 Dynamic strain similarity in vertebrates; an alternative to allometric limb bone scaling. Journal of Theoretical Biology 107 321-327. (doi:10.1016/S0022-5193(84)80031-4)

Saito M \& Bray G 1983 Diurnal rhythm for corticosterone in obese (ob/ ob) diabetes $(\mathrm{db} / \mathrm{db})$ and gold-thioglucose-induced obesity in mice. Endocrinology 113 2181-2185. (doi:10.1210/endo-113-6-2181)

Sattler FR 2013 Growth hormone in the aging male. Best Practice and Research in Clinical Endocrinology and Metabolism 27 541-555. (doi:10.1016/j.beem.2013.05.003)

Scibora LM 2014 Skeletal effects of bariatric surgery: examining bone loss, potential mechanisms and clinical relevance. Diabetes, Obesity and Metabolism 16 1204-1213. (doi:10.1111/dom.12363)

Scott D, Chandrasekara SD, Laslett LL, Cicuttini F, Ebeling PR \& Jones G 2016 Associations of sarcopenic obesity and dynapenic obesity with bone mineral density and incident fractures over 5-10 years in community-dwelling older adults. Calcified Tissue International 99 30-42. (doi:10.1007/s00223-016-0123-9)

Sessions ND, Halloran BP, Bikle DD, Wronski TJ, Cone CM \& MoreyHolton E 1989 Bone response to normal weight bearing after a period of skeletal unloading. American Journal of Physiology 257 E606-E610.

Shapses SA \& Riedt CS 2006 Bone, body weight, and weight reduction: what are the concerns? Journal of Nutrition 136 1453-1456.

Shapses SA \& Sukumar D 2012 Bone metabolism in obesity and weight loss. Annual Review of Nutrition 32 287-309. (doi:10.1146/annurev. nutr.012809.104655)

Sibonga JD 2013 Spaceflight-induced bone loss: is there an osteoporosis risk? Current Osteoporosis Reports 11 92-98. (doi:10.1007/s11914-0130136-5)

Sibonga JD, Zhang M, Evans GL, Westerlind KC, Cavolina JM, MoreyHolton E \& Turner RT 2000 Effects of spaceflight and simulated weightlessness on longitudinal bone growth. Bone 27 535-540. (doi:10.1016/S8756-3282(00)00352-5)
Sibonga JD, Evans HJ, Sung HG, Spector ER, Lang TF, Oganov VS, Bakulin AV, Shackelford LC \& LeBlanc AD 2007 Recovery of spaceflight-induced bone loss: bone mineral density after longduration missions as fitted with an exponential function. Bone $\mathbf{4 1}$ 973-978. (doi:10.1016/j.bone.2007.08.022)

Sibonga JD, Spector ER, Johnston SL \& Tarver WJ 2015 Evaluating bone loss in ISS astronauts. Aerospace Medicine and Human Performance 86 (12 Supplement) A38-A44. (doi:10.3357/AMHP.EC06.2015)

Sienkiewicz E, Magkos F, Aronis KN, Brinkoetter M, Chamberland JP, Chou S, Arampatzi KM, Gao C, Koniaris A \& Mantzoros CS 2011 Long-term metreleptin treatment increases bone mineral density and content at the lumbar spine of lean hypoleptinemic women. Metabolism 60 1211-1221. (doi:10.1016/j.metabol.2011.05.016)

Silva MJ 2007 Biomechanics of osteoporotic fractures. Injury 38 (Supplement 3) S69-S76. (doi:10.1016/j.injury.2007.08.014)

Skerry TM 2006 One mechanostat or many? Modifications of the site-specific response of bone to mechanical loading by nature and nurture. Journal of Musculoskeletal and Neuronal Interactions 6 122-127.

Snow CM, Shaw JM, Winters KM \& Witzke KA 2000 Long-term exercise using weighted vests prevents hip bone loss in postmenopausal women. Journals of Gerontology Series A: Biological Sciences and Medical Sciences 55 M489-M491. (doi:10.1093/gerona/55.9.m489)

Spector ER, Smith SM \& Sibonga JD 2009 Skeletal effects of long-duration head-down bed rest. Aviation, Space, and Environmental Medicine $\mathbf{8 0}$ A23-A28. (doi:10.3357/asem.br02.2009)

Stunes AK, Westbroek I, Gordeladze JO, Gustafsson BI, Reseland JE \& Syversen U 2012 Systemic leptin administration in supraphysiological doses maintains bone mineral density and mechanical strength despite significant weight loss. Endocrinology 153 2245-2253. (doi:10.1210/en.2011-1848)

Sugiyama T, Meakin LB, Browne WJ, Galea GL, Price JS \& Lanyon LE 2012 Bones' adaptive response to mechanical loading is essentially linear between the low strains associated with disuse and the high strains associated with the lamellar/woven bone transition. Journal of Bone and Mineral Research 27 1784-1793. (doi:10.1002/ jbmr.1599)

Talbott SM, Cifuentes M, Dunn MG \& Shapses SA 2001 Energy restriction reduces bone density and biomechanical properties in aged female rats. Journal of Nutrition $1312382-2387$.

Thompson WR, Rubin CT \& Rubin J 2012 Mechanical regulation of signaling pathways in bone. Gene 503 179-193. (doi:10.1016/j. gene.2012.04.076)

Tian X, Jee WS, Li X, Paszty C \& Ke HZ 2011 Sclerostin antibody increases bone mass by stimulating bone formation and inhibiting bone resorption in a hindlimb-immobilization rat model. Bone $\mathbf{4 8}$ 197-201. (doi:10.1016/j.bone.2010.09.009)

Trayhurn P \& James W 1978 Thermoregulation and non-shivering thermogenesis in the genetically obese (ob/ob) mouse. Pflugers Archiv 373 189-193. (doi:10.1007/BF00584859)

Trudel G, Payne M, Mädler B, Ramachandran N, Lecompte M, Wade C, Biolo G, Blanc S, Hughson R \& Bear L 2009 Bone marrow fat accumulation after 60 days of bed rest persisted 1 year after activities were resumed along with hemopoietic stimulation: the Women International Space Simulation for Exploration study. Journal of Applied Physiology 107 540-548. (doi:10.1152/ japplphysiol.91530.2008)

Turner R \& Iwaniec U 2010 Moderate weight gain does not influence bone metabolism in skeletally mature female rats. Bone $\mathbf{4 7}$ 631-635. (doi:10.1016/j.bone.2010.06.010)

Turner RT \& Iwaniec UT 2011 Low dose parathyroid hormone maintains normal bone formation in adult male rats during rapid weight loss. Bone 48 726-732. (doi:10.1016/j.bone.2010.12.034)

Turner RT 1995 Effects of short-term spaceflight and recombinant human growth hormone (rhGH) on bone growth in young rats. Aviation, Space, and Environmental Medicine 66 763-769. http://joe.endocrinology-journals.org

DOI: 10.1530/JOE-16-0089
๑ 2016 Society for Endocrinology Printed in Great Britain 
Turner RT 2000 Invited review: what do we know about the effects of spaceflight on bone? Journal of Applied Physiology 89 840-847.

Turner RT 2001 Skeletal adaptation to external loads optimizes mechanical properties: fact or fiction. Current Opinion in Orthopaedics 12 384-388. (doi:10.1097/00001433-200110000-00004)

Turner RT, Evans GL, Cavolina JM, Halloran B \& Morey-Holton E 1998 Programmed administration of parathyroid hormone increases bone formation and reduces bone loss in hindlimb-unloaded ovariectomized rats. Endocrinology 139 4086-4091. (doi:10.1210/ en.139.10.4086)

Turner RT, Kalra SP, Wong CP, Philbrick KA, Lindenmaier LB, Boghossian S \& Iwaniec UT 2013 Peripheral leptin regulates bone formation. Journal of Bone and Mineral Research 28 22-34. (doi:10.1002/jbmr.1734)

Turner RT, Philbrick KA, Wong CP, Olson DA, Branscum AJ \& Iwaniec UT 2014 Morbid obesity attenuates the skeletal abnormalities associated with leptin deficiency in mice. Journal of Endocrinology 223 M1-M15. (doi:10.1530/joe-14-0224)

Vergnaud AC, Norat T, Mouw T, Romaguera D, May AM, Bueno-deMesquita HB, van der Daphne A, Agudo A, Wareham N, Khaw KT, et al. 2013 Macronutrient composition of the diet and prospective weight change in participants of the EPIC-PANACEA study. PLOS ONE 8 e57300. (doi:10.1371/journal.pone.0057300)

Vico L, Collet P, Guignandon A, Lafage-Proust MH, Thomas T, Rehaillia M \& Alexandre C 2000 Effects of long-term microgravity exposure on cancellous and cortical weight-bearing bones of cosmonauts. Lancet 355 1607-1611. (doi:10.1016/S0140-6736(00)02217-0)

Vogiatzi MG, Autio KA, Mait JE, Schneider R, Lesser M \& Giardina PJ 2005 Low bone mineral density in adolescents with beta-thalassemia. Annals of the New York Academy of Sciences 1054 462-466. (doi:10.1196/annals.1345.063)

Von Thun NL, Sukumar D, Heymsfield SB \& Shapses SA 2014 Does bone loss begin after weight loss ends? Results 2 years after weight loss or regain in postmenopausal women. Menopause 21 501-508. (doi:10.1097/GME.0b013e3182a76fd5)

Wade CE 2005 Responses across the gravity continuum: hypergravity to microgravity. Advances in Space Biology and Medicine 10 225-245. (doi:10.1016/S1569-2574(05)10009-4)

Wang Q, Chen D, Cheng SM, Nicholson P, Alen M \& Cheng S 2015 Growth and aging of proximal femoral bone: a study with women spanning three generations. Journal of Bone and Mineral Research $\mathbf{3 0}$ 528-534. (doi:10.1002/jbmr.2353)

Weigle DS 1990 Human obesity. Exploding the myths. Western Journal of Medicine 153 421-428.

Weigle DS, Duell PB, Connor WE, Steiner RA, Soules MR \& Kuijper JL 1997 Effect of fasting, refeeding, and dietary fat restriction on plasma leptin levels. Journal of Clinical Endocrinology and Metabolism $\mathbf{8 2}$ 561-565. (doi:10.1210/jc.82.2.561)

Westerlind KC, Wronski TJ, Ritman EL, Luo Z-P, An K-N, Bell NH \& Turner RT 1997 Estrogen regulates the rate of bone turnover but bone balance in ovariectomized rats is modulated by prevailing mechanical strain. PNAS 94 4199-4204. (doi:10.1073/pnas.94.8.4199)

Wright NC, Saag KG, Curtis JR, Smith WK, Kilgore ML, Morrisey MA Yun H, Zhang J \& Delzell ES 2012 Recent trends in hip fracture rates by race/ethnicity among older US adults. Journal of Bone and Mineral Research 27 2325-2332. (doi:10.1002/jbmr.1684)

Xu H, Barnes GT, Yang Q, Tan G, Yang D, Chou CJ, Sole J, Nichols A Ross JS \& Tartaglia LA 2003 Chronic inflammation in fat plays a crucial role in the development of obesity-related insulin resistance. Journal of Clinical Investigation 112 1821. (doi:10.1172/JCI200319451)

Yu EW 2014 Bone metabolism after bariatric surgery. Journal of Bone and Mineral Research 29 1507-1518. (doi:10.1002/jbmr.2226)

Zhang P, Peterson M, Su GL \& Wang SC 2015 Visceral adiposity is negatively associated with bone density and muscle attenuation. American Journal of Clinical Nutrition 101 337-343. (doi:10.3945/ ajcn.113.081778)

Received in final form 22 June 2016

Accepted 27 June 2016

Accepted Preprint published online 27 June 2016
๑) 2016 Society for Endocrinology Printed in Great Britain 